\title{
RANCANG BANGUN AUGMENTED DAN VIRTUAL REALITY MENGGUNAKAN ALGORITMA FAST SEBAGAI MEDIA INFORMASI 3D DI UNIVERSITAS SATYA NEGARA INDONESIA
}

\section{Design Of Augmented And Virtual Reality Using FAST Algorithm As a 3D Information Media In Satya Negara Indonesia University}

\author{
Faizal Zuli, faizal.zuli@yahoo.com ${ }^{1)}$ \\ 1) Fakultas Teknik Univ. Satya Negara Indonesia
}

\begin{abstract}
The role of the media is quite important in providing information to the public about the University of Satya negara Indonesia. Delivery of information is usually done orally and in the form of a twodimensional such as posters, brochures, as well as through the website. Media such information certainly has its advantages and disadvantages respectively. For it makes the author want to design a media campaign to complement the usual media used by the campus. The making of a media promotion of the technology to implement multimedia computer, namely a merger between Augmented Reality (AR) and Virtual Reality (VR). Augmented Reality and Virtual Reality was selected because of its advantages in describing a building object in 3 dimensions $(3 D)$ in real time, to facilitate the user in knowing the information about the campus of the University of Satya negara Indonesia, which can be used on a Smartphone. In the design of inimenerapkan algorithm of FAST Corner Detection as well as using methods of Multimedia Development Life Cycle (MDLC).
\end{abstract}

Keyword : Augmented Reality, Satya Negara Indonesia University, Virtual Reality, 3D

\begin{abstract}
ABSTRAK
Peranan media merupakan hal yang cukup penting dalam memberi informasi kepada masyarakat luas mengenai Universitas Satya Negara Indonesia. Penyampaian informasi tersebut biasanya dilakukan secara lisan dan dalam bentuk dua dimensi seperti poster, brosur, serta melalui website. Media informasi tersebut tentu memiliki kelebihan dan kekurangan masing-masing. Untuk itu membuat penulis berkeinginan untuk merancang sebuah media promosi tambahan untuk melengkapi media yang biasa digunakan oleh kampus. Pembuatan media promosi tersebut mengimplementasikan teknologi multimedia komputer yaitu penggabungan antara Augmented Reality (AR) dan Virtual Reality (VR). Augmented Reality dan Virtual Reality dipilih karena kelebihannya dalam mendeskripsikan suatu objek bangunan secara 3 dimensi (3D) secara nyata, untuk mempermudah pengguna dalam mengetahui informasi tentang kampus Universitas Satya Negara Indonesia yang dapat digunakan pada Smartphone. Pada perancangan inimenerapkan algoritma FAST Corner Detection serta menggunakan metode Multimedia Development Life Cycle (MDLC).
\end{abstract}

Kata Kunci: Augmented Reality, Universitas Satya Negara Indonesia, Virtual Reality, 3D

\section{PENDAHULUAN}

Teknologi yang disebut Augmented Reality (AR), dan Virtual Reality (VR). Augmented Reality (AR) merupakan suatu upaya untuk menggabungkan dunia nyata dan dunia virtual yang dibuat melalui komputer sehingga batas antara keduanya menjadi sangat tipis. Sedangkan, Virtual Reality (VR) merupakan teknologi yang dibuat sehingga pengguna dapat berinteraksi dengan suatu lingkungan yang disimulasikan oleh komputer (computer- 
simulated environment). Dengan adanya teknologi multimedia memungkinkan pengguna untuk mendapatkan output dalam bentuk yang lebih menarik dibanding dengan media cetak maupun elektronik lain seperti bosur ataupun website. Berkembangnya teknologi multimedia dalam menyajikan suatu informasi sangatlah tampak, karena disajikan dalam objek-objek multimedia seperti : teks, grafik, suara, video, maupun animasi yang diharapkan dapat menjadi lebih interaktif, sehingga informasi yang ditampilkan tidak hanya terbatas dalam model teks tetapi penggabungan dari objek-objek multimedia tersebut, sehingga pengguna lebih tertarik untuk melihat informasi yang disajikan.

Berbagai penelitian terkait dari topik yang diangkat penulis pernah dilakukan oleh peneliti terdahulu, hasil penelitian yang dikemukakan menunjukan berbagai cara untuk membuat aplikasi augmented reality (AR) dan virtual reality (VR).

Yudi Nugraha Bahar pada tahun 2014 melakukan penelitian dengan judul "Aplikasi Teknologi Virtual Realty Bagi Pelestarian Bangunan Arsitektur" yang membahas teknologi visualisasi dan simulasi melalui Virtual Reality (VR) dalam bidang arsitektur khususnya berkaitan dengan pelestarian warisan sejarah atau preservasi dan konservasi digital. Sehingga memungkinkan situs heritage direkonstruksi kembali dengan sangat akurat, model 3D, interaktif dan dapat disajikan real-time.

Galih Mahendra pernah melakukan penelitian dengan judul "Pembuatan dan Implementasi Pengolahan Citra Digital Pada Augmented Reality Berbasis Web" yang membahas pembuatan dan pengimplementasian pengolahan citra digital pada augmented reality dengan menggunakan 4 model monumen antara lain ; monumen nasional, monumen proklamator, monumen patung dirgantara (tugu pancoran), dan monumen pemuda pembangunan. Dalam penelitian tersebut dibuat pula buku yang dapat menampilkan model monumen secara 3D dengan bantuan webcam pada Personal computer (PC).

Kembang Hapsari, Nur Sulaiman, Luky Agus Hermanto dengan judul "Aplikasi Findgo-ITATS Berbasis Android Dengan Algoritma SURF Untuk Menampilkan Informasi Lokasi Di ITATS". Aplikasi tersebut menggunakan teknologi augmented reality untuk mempermudah bagi orang awam yang ingin mengunjungi tempattempat yang ada di Institut Teknologi Adhi Tama Surabaya (ITATS). Penelitian tersebut mengimplementasikan teknologi Augmented Reality (AR) pada smartphone bersistem operasi android dengan menggunakan algoritma SURF (Speeded Up Robust Features) untuk mengenali gambar.

Menurut Vaughan dalam (Binanto, 2010), multimedia merupakan kombinasi teks, seni, suara, gambar, animasi, dan video yang disampaikan dengan komputer atau dimanipulasi secara digital dan dapat disampaikan dan/atau dikontrol secara interaktif. Ada tiga jenis multimedia yaitu :

1. Multimedia interaktif

Pengguna dapat mengontrol apa dan kapan elemen-elemen multimedia akan dikirimkan atau ditampilkan.

2. Multimedia hiperaktif

Multimedia jenis ini mempunyai suatu struktur dari elemen-elemen terkait dengan pengguna yang dapat mengarahkannya.dapat dikatakan bahwa multimedia jenis ini mempunyai banyak tautan (link) yang menghubungkan elemen-elemen multimedia yang ada.

3. Multimedia linear

Pengguna hanya menjadi penonton dan menikmati produk multimedia yang disajikan dari awal hingga akhir.

Dari definisi di atas, sebuah sistem multimedia dapat digambarkan seperti gambar berikut. 


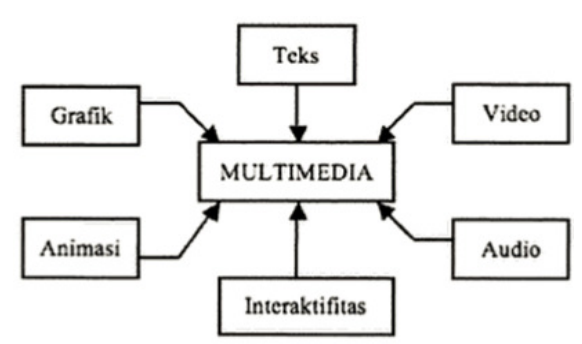

\section{Gambar 1. Gambaran definisi multimedia}

Dari definisi multimedia diatas terdapat enam jenis objek multimedia : teks, grafis, bunyi, video, animasi, dan software yang masing-masing objek memiliki peran dalam keseluruhan sistem multimedia dalam menyampaikan informasi. Menurut M. Suyanto dalam AT Rohman (2014) menjelaskan objek-objek tersebut.

Bentuk data multimedia yang paling mudah disimpan dan dikendalikan adalah teks. Teks dapat membentuk kata, surat atau narasi dalam multimedia yang menyajikan bahasa. Kebutuhan teks bergantung pada kegunaan aplikasi multimedia. Misalnya, game membutuhkan teks lebih sedikit, seperti ditunjukan pada Gambar 2

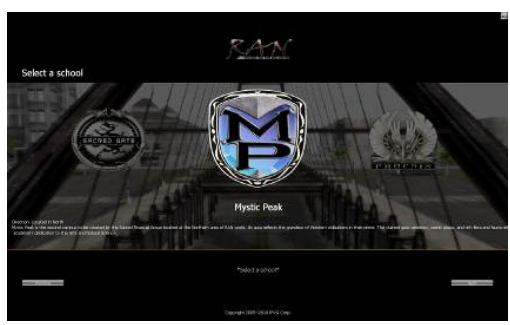

Gambar 2. Game membutuhkan teks lebih sedikit

\footnotetext{
Sedangkan

membutuhkan teks lebih banyak, ditunjukan pada Gambar 3.
}

Menggunakan gambar dalam presentasi atau publikasi multimedia adalah karena lebih menarik perhatian dan dapat mengurangi kebosanan dibandingkan dengan teks. Gambar dapat meringkas dan menyajikan data kompleks dengan cara yang baru dan lebih berguna. Sering dikatakan bahwa sebuah gambar mampu menyampaikan seribu kata. Grafis seringkali muncul sebagai backdrop (latar belakang) suatu teks untuk menghadirkan kerangka yang mempermanis teks. Picture (gambar) juga bisa berfungsi sebagai ikon, yang bila dipadu dengan teks, menunjukan berbagai opsi yang bisa dipilih (select); atau gambar bisa muncul full-screen menggantikan teks, tapi tetap memiliki bagian-bagian tertentu yang berfungsi sebagai pemicu yang bila diklik akan menampilkan objek atau event multimedia lain.

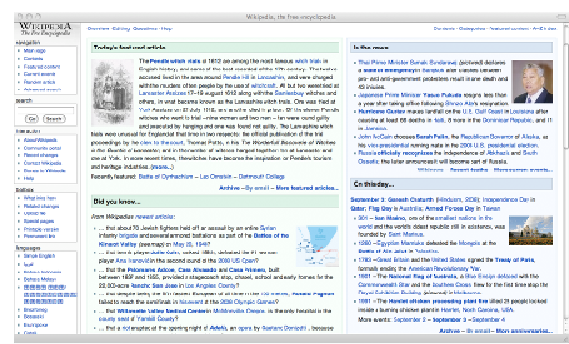

\section{Gambar3..Ensiklopedia membutuhkan teks lebih banyak}

Bunyi dalam PC multimedia, khususnya pada aplikasi bidang bisnis dan game sangat bermanfaat. PC multimedia tanpa bunyi hanya disebut unimedia, bukan multimedia. Kemampuan dasar bunyi yang harus dimiliki PC multimedia antara lain : membuat dan mensintesis bunyi, menangkap bunyi dari dunia luar, mengendalikan bunyi yang dibuat dari instrument elektronik misalnya MIDI, memainkan kembali bunyi terebut lewat speaker atau sejenisnya.

Masing-masing kemampuan membutuhkan teknologi, perangkat keras 
dan perangkat lunak untuk menjalankannya. Bunyi dapat ditambahkan dalam produksi multimedia melaui suara, musik dan efekefek suara.

Ada tiga belas jenis objek bunyi yang biasa digunakan dalam produksi multimedia, yakni format wavefrom audio, aiff, dat, ibf, mod, rmi, sbi, snd, voc, au, MIDI sound track, compact disc audio, dan mp3 file.

Video menyajikan sumberdaya yang kaya dan hidup bagi aplikasi multimedia, ada empat macam video yang dapat digunakan sebagai objek link dalam aplikasi multimedia : life video feed, videotape, videodisc, dan digital video.

Dalam multimedia, animasi merupakan penggunaan komputer untuk menciptakan gerak pada layar. Ada Sembilan macam, yaitu animasi sel, animasi frame, animasi sprite, animasi lintasan, animasi spline, animasi vektor, animasi karakter, animasi computation, dan morphing.

Salah satu konsep paling ampuh dalam multimedia adalah keterpaduan serempak yang dapat dicapai dengan menciptakan link keberbagai dokumen dan dataset. Saat pemakai memicu satu link ke suatu dokumen wordprocessor, seperti file .doc di Microsoft Word misalnya, maka komputer akan secara otomatis meluncurkan aplikasi perangkat lunak (pada contoh ini MS Word) dan menggunakannya untuk menampilkan dokumen yang dimaksud.

Grafik komputer 3 dimensi atau biasa disebut 3D adalah bentuk dari benda yang memiliki panjang, lebar, dan tinggi. Grafik 3 Dimensi merupakan teknik penggambaran yang berpatokan pada titik koordinat sumbu $\mathrm{x}$ (datar), sumbu y(tegak), dan sumbu $\mathrm{z}$ (miring). Grafik 3D merupakan perkembangan dari grafik 2D. Didalam grafika komputer, 3D merupakan bentuk grafik yang menggunakan representasi data geometri tiga dimensi.

Perbedaan paling utama dari objek 2 dimensi dan objek 3 dimensi yaitu kedalamannya, yaitu suatu jarak antara pengamat dengan suatu objek yang dilihat (point of view). Jadi, jika objek 2 dimensi hanya menggunakan 2 ukuran (panjang dan lebar), maka 3 dimensi menggunakan 3 ukuran meliputi panjang, lebar, kedalaman yang disimbolkan dengan sumbu $\mathrm{x}, \mathrm{y}, \mathrm{z}$.

Proses pembuatan grafik komputer 3D dapat dibagi ke dalam tiga fase, yaitu 3D modeling yang mendeskripsikan bentuk dari sebuah objek, layout dan animation yang mendeskripsikan gerakan dan tata letak sebuah objek, dan 3D rendering yang memproduksi image dari objek tersebut. (Edy Irwansyah, Jurike V. Moniaga, 2014)

FAST (Feture Form Accelerated segment Test) adalah suatu algoritma yang dikembangkan oleh Edward Rosten, Reid Porter, and Tom Drummond. FAST Corner Detection ini dibuat dengan tujuan mempercepat waktu komputasi secara realtime dengan konsekuensi menurunkan tingkat akurasi pendeteksian sudut. interest point detection (deteksi titik minat) nama lain dari Corner Detection(deteksi sudut) adalah suatu pendekatan yang digunakan dalam Computer Vision (visi komputer) sistem dan proses segmentasi untuk mengambil beberapa sudut dari suatu objek dan menyimpulkan isi dari suatu images. Deteksi sudut sering digunakan dalam mendeteksi gerakan, pencocokan gambar, pelacakan, 3D modeling dan pengenalan obyek.

Adapun definisi dari sudut sendiri adalah perpotongan antara dua sisi (edge). Sebuah sudut juga dapat didefinisikan sebagai titik yang memiliki dua sisi dominan dan berbeda arah dari titik tersebut (Afissunani, Saleh, \& Assidiqi, 2012). Dalam hal ini, sudut akan dimanfaatkan sebagai informasi sebuah 
image sehingga sebuah objek image dapat dengan mudah dikenali dengan menyematkan corner point pada titik minat(interest point) sebuah objek image. Pada FASTCorner Detection, proses penentuan corner point-nya adalah dengan cara merubah gambar menjadi warna hitamputih dan menjalankan algoritmanya.

Algoritma FAST Corner Detection bekerja pada citra sebagai berikut:

1.Tentukan sebuah titik $\mathrm{p}$ pada citra dengan posisi awal (Xp,Yp) seperti pada gambar 5.

2.Tentukan keempat titik. Titik pertama $(n=1)$ terletak pada koordinat $(\mathrm{Xp}, \mathrm{Yp}+3)$, titik kedua $(\mathrm{n}=2)$ terletak pada koordinat $(X p+3, Y p)$, titik ke tiga $(\mathrm{n}=3)$ terletak pada koordinat $(\mathrm{Xp}, \mathrm{Yp}-3)$, titik keempat $(n=4)$ terletak pada koordinat (Xp-3,Yp).

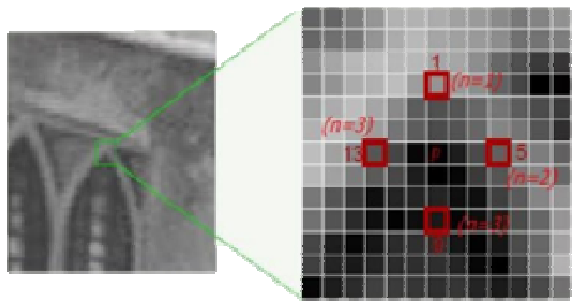

Gambar 5. titik p terletak pada koordinat $n=1, n=2, n=3$ dan $n=4$

3. Bandingkan intensitas titik pusat $p$ dengan keempat titik disekitar. Jika terdapat paling sedikit 3 titik yang memenuhi syarat berikut, maka titik pusat $p$ adalah titik sudut. Seperti pada rumus (1)

$C p= \begin{cases}1, \ln <\operatorname{lp}-t \text { or } \ln >\operatorname{lp}+t \\ 0, & \text { otherwise }\end{cases}$

Keterangan:

$\mathrm{Cp}$ : Keputusan titik p sebagai sudut, nilai 1 menunjukan bahwa titik merupakan suatu sudut, dan nilai 0 menunjukan bahwa titik bukanlah sudut

In : Nilai intensitas piksel ke-n
Ip : Nilai intensitas titik $\mathrm{p}$

$\mathrm{T}$ : Batas ambang nilai intensitas yang ditoleransi

Ulangi proses sampai seluruh titik pada citra sudah dibandingkan intensitasnya.

Tahap pertama inisialisasi $\mathrm{n}$ sebagai deteksi sudut, lalu sudut terdeteksi dari satu set gambar menggunakan kriteria uji untuk segmen $\mathrm{n}$ dalam pencocokan threshold (teknik segmentasi yang menampilkan gambar dengan dua macam warna saja yaitu hitam dan putih). Untuk setiap piksel hanya menguji semua 16 lokasi pada lingkaran di sekitarnya. Setiap nilai (salah satu dari 16 piksel, katakanlah x) dalam vektor, dapat mengambil tiga bagian. Lebih gelap dari $\mathrm{p}$, lebih cerah dari $\mathrm{p}$ atau mirip dengan $\mathrm{p}$. Berikut adalah rumus matematikanya ditunjukkan pada rumus (2):

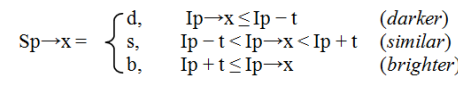

$\mathrm{Sp} \rightarrow \mathrm{x}$ adalah bagian, $\mathrm{Ip} \rightarrow \mathrm{x}$ adalah intensitas piksel $\mathrm{x}$. dan $\mathrm{t}$ adalah threshold. Tahap selanjutanya membuat decision tree yang dapat mengklasifikasi Interest point dalam 16 lokasi.

Augmented Reality (AR) adalah kombinasi antara dunia maya (virtual) dan dunia nyata (real) yang dibuat oleh komputer. Objek virtual dapat berupa teks, animasi, model 3D atau video yang digabungkan dengan lingkungan sebenarnya sehingga penggunadapat merasakan objek virtual berada dilingkungannya. AR adalah cara baru dan menyenangkan dimana manusia berinteraksi dengan komputer, karena dapat membawa objek virtual ke lingkungan pengguna, memberikan pengalaman visualisasi yang alami dan menyenangkan. Sistem ini berbeda dengan Virtual Reality 
(VR), yang sepenuhnya merupakan virtual environment.

$$
\text { Dengan bantuan teknologi }
$$

Augmented Reality, lingkungan nyata di sekitar kita akan dapat berinteraksi dalam bentuk digital (virtual). Informasi tentang objek dan lingkungan di sekitar kita akan dapat ditambahkan kedalam sistem Augmented Reality yang kemudian informasi tersebut ditampilkan diatas layer dunia nyata secara real-time seolah-olah informasi tersebut adalah nyata. Suryawinata (2010).

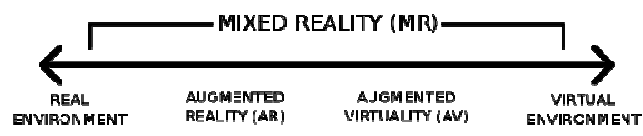

Gambar 6. Grafik Milgram Continuum

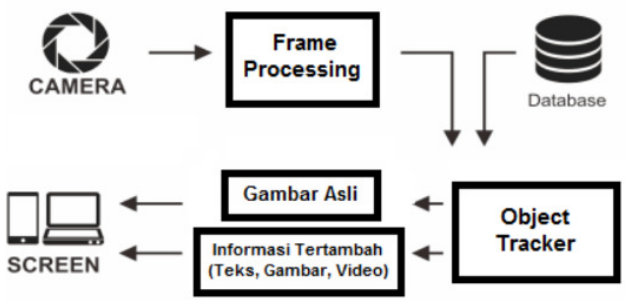

Gambar 7. Alur kerja Augmented Reality

$$
\text { Augmented Reality }
$$
merupakan salah satu cabang di bidang teknologi yang belum terlalu lama, namun memiliki perkembangan yang sangat cepat. Perkembangan Augmented Reality pada industri mobile phone juga mempunyai perkembangan yang paling cepat.

Virtual Reality (VR) atau realitas maya adalah teknologi yang membuat pengguna dapat berinteraksi dengan suatu lingkungan yang disimulasikan oleh komputer (computer simulated environment), suatu lingkungan sebenarnya yang ditiru atau benar-benar suatu lingkungan yang hanya ada dalam imaginasi. Lingkungan realitas maya terkini umumnya menyajikan pengalaman visual, yang ditampilkan pada sebuah layar komputer atau melalui sebuah penampil stereokopik, tapi beberapa simulasi mengikutsertakan tambahan informasi hasil pengindraan, seperti suara melalui speaker atau headphone. Sihite (2013).

Unity Engine suatu game engine yang terus berkembang sejak dibangun pada tahun 2004. Engine ini merupakan salah satu game engine dengan lisensi source proprietary, namun untuk lisensi pengembangan dibagi menjadi 2, yaitu free (gratis) dan berbayar sesuai perangkat target pengembangan aplikasi. Unity tidak membatasi publikasi aplikasi, pengguna unity dengan lisensi gratis dapat mempublikasikan aplikasi yang dibuat tanpa harus membayar biaya lisensi atau royalti kepada unity. Tetapi penggunaan versi free dibatasi dengan beberapa fitur yang dikurangi atau bonus modul/prefab tertentu yang ditiadakan dan hanya tersedia untuk pengguna berbayar.

Unity Engine memiliki kerangka kerja (framework) lengkap untuk pengembangan profesional. Sistem inti engine ini menggunakan beberapa pilihan

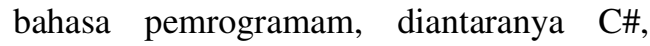
javascript maupun boo. Unity3D editor menyediakan beberapa alat untuk mempermudah pengembangan yaituUnity Tree dan terrain creator untuk mempermudah pembuatan vegetasi dan terrain serta MonoDevelop untuk proses pemrograman. Dari beberapa game engineyang sama-sama menangani grafik tiga dimensi, Unity Engine dapat menangani lebih banyak. Beberapa diantaranya yaitu Windows, MacOS X, iOS, PS3, wii, Xbox 360, dan Android yang lebih banyak daripada game engine lain seperti Source Engine, GameMaker, Unigine, id Tech 3 Engine, id Tech 4 Engine, Blender Game Engine, NeoEngine, 
Unity, Quake Engine, C4 Engine atau game engine lain. Rickman (2015).

Vuforia adalah Augmented Reality Software

Development Kit (SDK) untuk perangkat mobile yang memungkinkan pembuatan aplikasi Augmented Reality. SDK Vuforia juga tersedia untuk digabungkan dengan unity yaitu bernama Vuforia AR Extension for Unity. Vuforia merupakan SDK yang disediakan oleh Qualcomm untuk membantu para developer membuat aplikasi-aplikasi Augmented Reality (AR) di mobile phones (iOS, Android). SDK Vuforia sudah sukses dipakai di beberapa aplikasi-aplikasi mobile untuk kedua platform tersebut. AR Vuforia memberikan cara berinteraksi yang memanfaatkan kamera mobile phones untuk digunakan sebagai perangkat masukan, sebagai mata elektronik yang mengenali penanda tertentu, sehingga di layar bisa ditampilkan perpaduan antara dunia nyata dan dunia yang digambar oleh aplikasi. (Mahendra, 2016)

Google SketchUp adalah program grafis 3D yang dikembangkan oleh Google yang mengombinasikan seperangkat alat (tools) yang sederhana, namun sangat handal dalam desain grafis 3D di dalam layar komputer. Selain fitur-fiturnya yang user friendly, Google SketchUp juga tersedia secara gratis (kecuali untuk versi Pro) bagi semua orang yang tertarik untuk mempelajari dunia grafis 3D, sesuai dengan tagline yang diembannya, yakni ' $3 D$ Modelling for Everyone'. (SIA Setiawan, 2011)

\section{METODE PENELITIAN}

Mengacu pada tahap analisis yang telah dilakukan, peneliti melanjutkan ke tahap perancangan dan pengembangan. Tahap perancangan dimulai dengan pembuatan aplikasi berbasis augmented reality dan virtual reality yang akan dikembangkan

Marker yang digunakan pada aplikasi ini dibuat dari hasil scan brosur kampus Universitas Satya Negara Indonesia yang sudah ada. Proses pembuatan gambar menjadi marker dilakukan oleh Vuforia, yaitu dengan cara mengupload gambar marker pada laman web developer Vuforia. Setelah gambar di convert menghasilkan file dengan format .unitypackage. File tersebut kemudian dijadikan masukan pada Engine Unity3D untuk mendeteksi gambar yang dijadikan marker. Format gambar yang dapat dijadikan marker adalah harus berformat .jpg atau .png, ukuran gambar tidak lebih dari $2 \mathrm{MB}$, warnanya harus RGB atau grayscale (bukan CMYK), serta gambar harus memiliki feature. Feature dalam gambar artinya adalah gambar tersebut memiliki sudut.

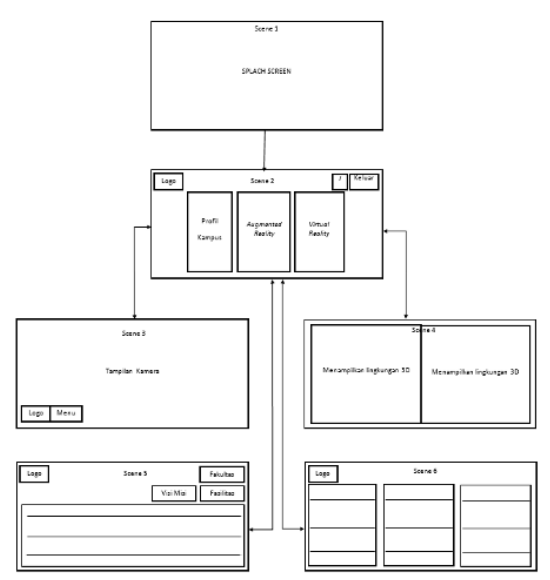

\section{Gambar 8. Storyboard Perancangan aplikasi}
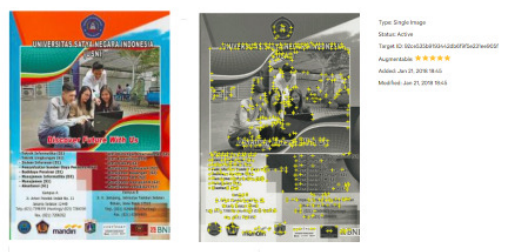


\section{Gambar 9. Marker yang sudah didaftarkan pada Vuforia}

Pada gambar hasil scan (kiri) akan diberikan feature oleh vuforia sehingga dapat dikenali, feature tersebut dapat dilihat pada gambar marker target (kanan) yang terdapat titik-titik kuning. Pemberian feature tersebut merupakan hasil pengolahan algoritma FAST Corner Detection yang ada pada vuforia, semakin banyak titik yang terdapat pada gambar mengindikasikan jumlah sudut yang ada pada gambar tersebut cukup banyak hal tersebut dapat dilihat dari peringkat augmentable yang mendapatkan 5 bintang penuh

Setelah model telah selesai dibuat maka model 3D dapat digunakan dalam aplikasi augemnted realitydan virtual realityUniversitas Satya Negara Indonesia. pemodelan yang peneliti buat yaitu pemodelan Gedung yang ada di Universitas Satya Negara Indonesia. Model 3D yang dibuat berdasarkan hasil observasi peneliti yang didokumentasikan ke dalam foto maupun video. Model 3D dibuat menggunakan software SketchUp dengan format akhir berkekstensi .fbx. Berikut hasil dari Modeling Model 3D:

Hasil Modeling Gedung Auditorium Universitas Satya Negara Indonesia. Diperagakan pada gambar 10.

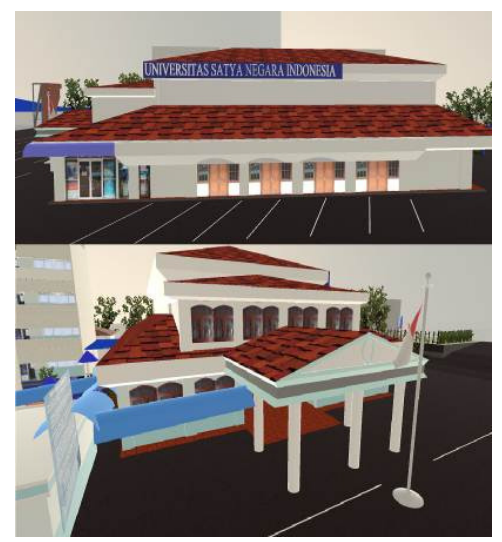

\section{Gambar10. Model 3D auditorium}

Hasil Modeling Gedung L Universitas Satya Negara Indonesia. Diperagakan pada gambar 11.

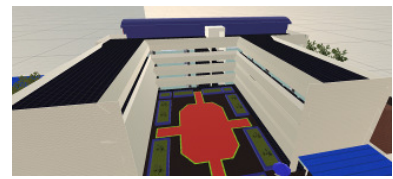

\section{Gambar 11. Model 3D Gedung L}

\section{Hasil Modeling Gedung D}

Universitas Satya Negara Indonesia. Diperagakan pada gambar 12.

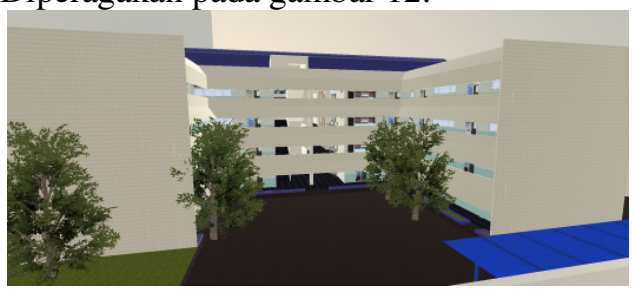

Gambar 12. Model 3D Gedung D

Hasil ModelingMushola Universitas Satya Negara Indonesia. Diperagakan pada gambar 13.

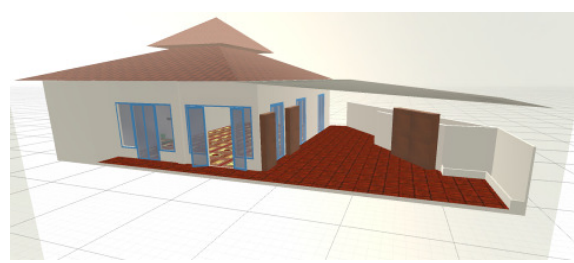

Gambar 13. Model 3D Mushola

Hasil ModelingKantin Universitas Satya Negara Indonesia. Diperagakan pada ambar 14..

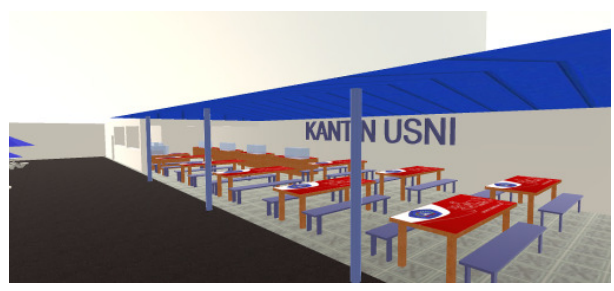




\section{Gambar 14. Model 3D Kantin}

Hasil Modelingkantor yayasan Universitas Satya Negara Indonesia. Diperagakan pada gambar 15.

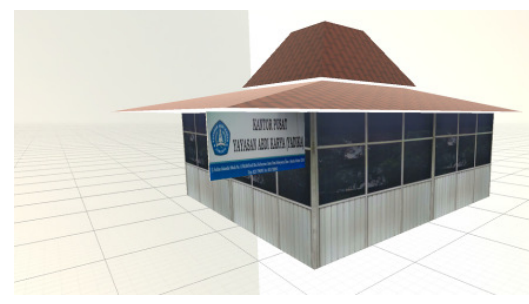

\section{Gambar 15. Model 3D Kantor yayasan}

Hasil ModelingLapangan Olahraga Universitas Satya Negara Indonesia. Diperagakan pada gambar 16.

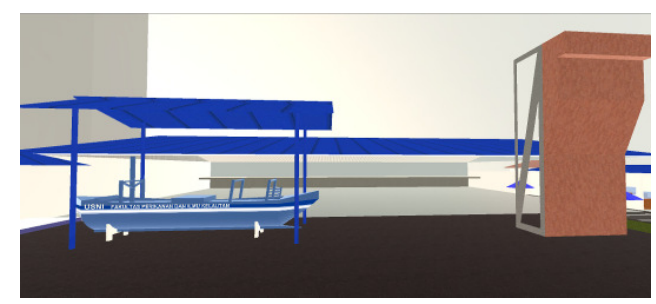

Gambar 16. Model 3D Lapangan Olahraga

Hasil ModelingPos keamanan Universitas Satya Negara Indonesia. Diperagakan pada gambar 17.

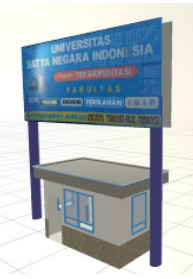

\section{Gambar 17. Model 3D Pos Keamanan}

Hasil ModelingLab komputer Universitas Satya Negara Indonesia. Diperagakan pada gambar 18.

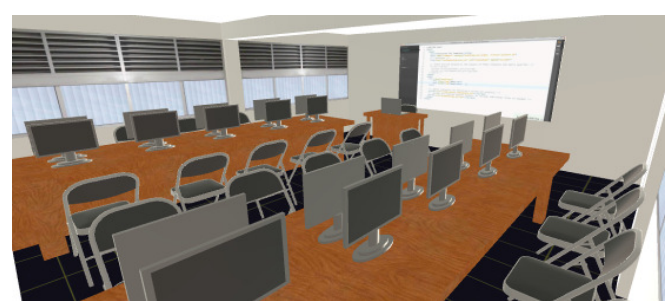

Gambar 18. Model 3D Lab komputer

Hasil ModelingLingkungan Universitas Satya Negara Indonesia diperagakan pada gambar 19.

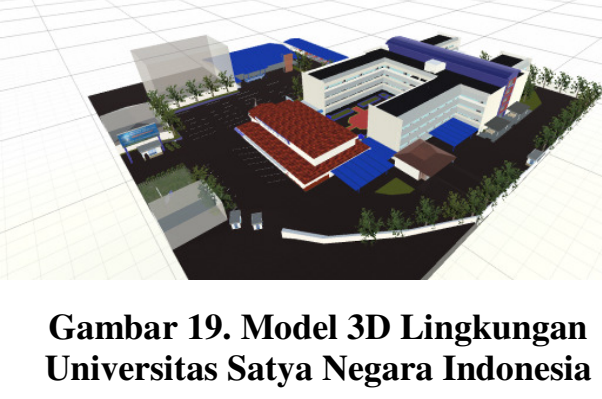

Setelah mendapatkan model 3 dimensi dan marker yang diharapkan, selanjutnya adalah menggabungkan komponen tersebut seperti pada gambar 20 , dan mengujinya

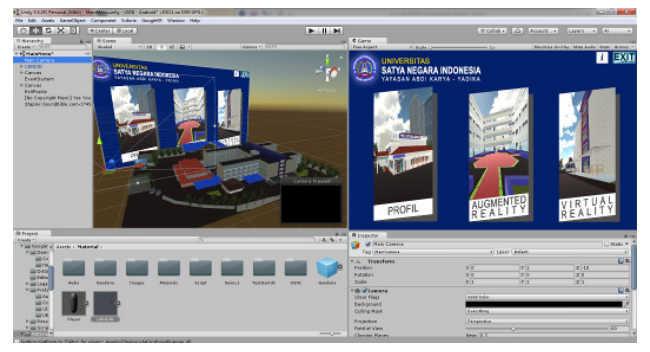

Gambar 20. Proses assembling menggunakan unity

\section{HASIL DAN PEMBAHASAN}

Setelah semua bahan diproses baru kemudian di-built dalam bentuk package yang siap digunakan. Hasil yang didapat 
setelah di-built adalah file .apk untuk selanjutnya dilakukan pengujian. Pengujian aplikasi merupakan hal terpenting yang dilakukan untuk menemukan kekurangan atau kesalahan pada aplikasi yang diuji. Pengujian bermaksud untuk mengetahui aplikasi yang dibuat sudah memenuhi kriteria yang sesuai dengan tujuan perancangan. Adapun metode pengujian yang digunakan pada perangkat lunak ini adalah metode pengujian black box. pengujian black boxcenderung dilakukan untuk menemukan hal-hal seperti fungsi tidak benar atau tidak ada, kesalahan antar muka (interface error), kesalahan pada struktur data dan akses basis data, kesalahan performasi (performance error)serta kesalahan inisialisasi dan terminasi.

Metode pengujian black box sendiri terdiri dari dua tahapan pengujian yaitu tahap pengujian alpha dan tahap pengujian beta. Akan tetapi pada penelitian ini peneliti hanya pada tahap pengujian alpha (alpha test)dimana pengujiandilakukan oleh pembuat atau lingkungan pembuatnya sendiri dengan melakukan pengujian instalasi aplikasi pada beberapa perangkat serta pengujian fungsionalitas sistem termasuk desain interface, suara,pengecekan ketepatan objek berdasarkan marker maupun materi yang ditampilkan sudah sesuai standar GUI (Graphical User Interface) sehingga memudahkan pengguna dalam berinteraksi dengan aplikasi.

\section{SIMPULAN}

Berdasarkan penelitian yang telah dilakukan, didapat kesimpulan bahwa penelitian yang dilakukan telah berhasil merancang dan membangun aplikasi Augmenteddan Virtual Reality yang berjalan sesuai dengan perancangan awal yakni dapat menampilkan lingkungan Virtual 3 dimensi kampus Universitas Satya
Negara Indonesia.Aplikasi Augmenteddan Virtual Realitydibangun dengan menggunakan GameEngine Unity 3D dengan bantuan Vuforia SDK dalam pembuatan Augmented Reality dan Google VR SDK dalam pembuatan Virtual Reality sehinga aplikasi ini dapatmenampilkan secara real-time objek 3Dkampus Universitas Satya Negara Indonesia.

Penerapan metode Multimedia Development Life Cycle(MDLC) juga dapat memberi manfaat yang baik bagi penulismulai dari tahap pertama yakni Concept sampai Distribution aplikasi. Hal ini dikarenakan Multimedia Development Life Cycle(MDLC), ini dilakukan secarabertahap dan terstruktur. Sehingga jika terjadi kesalahan dalam salah satutahap, maka perbaikan akan cepat dapat dilakukan.

\section{DAFTAR PUSTAKA}

[1] Afissunani, A., Saleh, A., \& Assidiqi, M. H. (2012). Multi Marker Augmented Reality Untuk Aplikasi Magic Book. Dari repo.pens.ac.id/1092/1/paper_afis.doc.p df

[2] AT Rohman, 2014. Perancangan Komunikasi Visual Berbasis Multimedia Pada Produk "Cloud" Dari PT. Rect Media Komputindo Semarang.

[3] Sihite, F. Samopa dan N. A. Sani, (2013). Pembuatan Aplikasi 3D Viewer Mobile dengan Menggunakan Teknologi Virtual Reality (Studi Kasus: Perobekan Bendera Belanda di Hotel Majapahit), Teknik Pomits, vol. 2, 2013.

[4] Binanto, Iwan (2010). Multimedia Digital : Dasar Teori + Pengembangannya. Yogyakarta: Andi. 
[5] Irwansyah, Edy dan Jurike V. Moniaga. (2014). Pengantar Teknologi Informasi. Yogyakarta: deePublish.

[6] Mahendra, Ida Bagus Made (2016). Implementasi Augmented Reality (AR) Menggunakan Unity 3D Dan Vuporia Sdk.

Dari https://ojs.unud.ac.id/index.php/jik/artic le/view/26341

[7] Mustaqbal M.Sidi, Roeri Fajri Firdaus, Hendra Rahmadi. 2015. Pengujian Aplikasi Menggunakan Black box Testing Boundary Value Analysis (Studi Kasus : Aplikasi Prediksi Kelulusan SNMPTN). Jurnal Ilmiah Teknologi Informasi Terapan. Vol.I, No.3.

[8] Roedavan, Rickman. (2015). Unity Tutorial Game Engine Edisi Revisi.Bandung : Informatika.

[9] S. I. A. Setiawan, "Google SketchUp Perangkat Alternatif dalam Pemodelan
3D,"

2011.

Dari

ejournals.umn.ac.id/index.php/TI/articl e/viewFile/298/264

[10] Safaat. H,Nazruddin (2012). Pemrograman Aplikasi Mobile Smartphone dan. Tablet PC berbasis android, Revisi Kedua, Bandung : Informatika.

[11] Suryawinata B. A. (2010). Pemanfaatan Augmented Reality Dalam Memvisualisasikan Produk Perumahan Melalui Internet. ComTech, 1 (2), 758-769. 